\title{
Seed Germination and Initial Stages of Tripogon chinensis (Poaceae) Ontogenesis
}

\author{
Irina N. Plyaskina and Evgenii A. Bondarevich* \\ Chita State Medical Academy \\ 39 A Gor'ky Str., Chita, 672000, Russia
}

Received 10.11.2018, received in revised form 01.02.2019, accepted 18.03.2019

This paper presents the results of research of Tripogon chinensis adaptation mechanisms to the environmental conditions. This relict cereal grows on petrophytic parts of the slopes, where it is affected by extreme environmental factors (temperature variations, lack of water, insolation, etc.). This cereal reproduces by seeds. Under such growth conditions, to be able to germinate and continue growing, the plant must effectively use the available moisture and the seed storage compounds. Experiments with seeds germinated under different moisture conditions showed the ability of $T$. chinensis seeds to germinate in substrates with widely varying moisture contents. Increased moisture adversely affected the process of germination and growth of the cereal. Seed storage proteins play a special role because they are used as source of amino acids for the synthesis of proteins necessary for the plant. Determination of the fraction composition of T. chinensis seed storage proteins showed the high content of albumins and globulins (45\% of the total weight of storage proteins), which ensured germination under water deficit. The study showed that germinating T. chinensis seeds use prolamins (their concentration decreases fourfold during germination). The considerable prolamin content of seeds (37\%) and prolamin dynamics during germination support the hypothesis on the adaptive role of prolamins, as they contain amino acids essential for the seedling. Thus, morphological, physiological and biochemical properties of this cereal characterize it as a xerophytic species, which developed due to a combination of environmental factors of the Eastern Transbaikal region.

Keywords: adaptation, seed germination, osmotic stress of seeds, storage proteins, Tripogon chinensis.

Citation: Plyaskina I.N., Bondarevich E.A. Seed germination and initial stages of Tripogon chinensis (Poaceae) ontogenesis. J. Sib. Fed. Univ. Biol., 2019, 12(1), 71-85. DOI: 110.17516/1997-1389-0289.

(C) Siberian Federal University. All rights reserved

This work is licensed under a Creative Commons Attribution-NonCommercial 4.0 International License (CC BY-NC 4.0).

* Corresponding author E-mail address: thebestdamnthing@mail.ru 


\title{
Прорастание семян и начальные этапы онтогенеза Tripogon chinensis (Poaceae)
}

\author{
И.Н. Пляскина, Е.А. Бондаревич \\ Читинская государственная медииинская академия \\ Россия, 672000, Чита, ул. Горького, $39 \mathrm{~A}$
}

В статье представлены результаты исследований механизмов адаптации Tripogon chinensis к условиям среды. Это реликтовый злак, имеющий особенные условия произрастания петрофитные участки склонов, где он оказывается под действием экстремальных факторов среды (колебания температуры, недостаточное увлажнение, инсоляция и т.д.). Численность популяции этого злака поддерживается путем семенного размножения. В подобных условиях для прорастания и дальнейтего роста злакунеобходимо эффективно использовать имеюшуюся влагу и запасные вещества семени. Опыты по проращиванию семян в условиях различной влагообеспеченности субстрата показали способность семян T. chinensis прорастать 6 широком диапазоне влажности. Избыточное увлажнение негативно сказалось на процессах прорастания и роста злака. Особую роль имеют белки, в частности запасные, которые являются источником аминокислот, используемых для синтеза необходимых проросткубелков, в биоэнергетических прочессах и других метаболических путях. В результате определения фракционного состава запасных белков семян T. chinensis установлено высокое содержание альбуминов и глобулинов (45\% от общей массы запасных белков), которые обеспечивают образование осмолитов в условиях недостатка влаги. Исследования показали, что семена T. chinensis при прорастании активно используют проламиновую фракиию (ее концентрация при прорастании уменьшается в 4 раза). Значительное содержание проламиновой фракции в сухих семенах (37 \%) и ее динамика при прорастании поддерживают гипотезу об адаптивной роли проламинов, посколькуони содержат важные для проростка аминокислоты (например, пролин). Таким образом, морфологические, физиологические и биохимические особенности исследуемого злака характеризуют его как вид, имеющий ксероморфную природу, сформировавщуюся под действием комплекса факторов среды Восточного Забайкалья. Семена T. сhinensis при этом имеют ряд адаптаций, позволяющих им сохраняться в почве и прорастать при наступлении оптимальных условий.

Ключевые слова: адаптация, прорастание семян, осмотический стресс семян, запасные белки, Tripogon chinensis.

\section{Введение}

Растительный покров степей Восточного Забайкалья сформировался в ходе длительной эволюции. Климат региона изменился с теплого гумидного (палеоген, неоген) на холодный аридный (антропоген) (Пешкова, 1972). При- чин этих изменений множество, что связано, прежде всего, с геологическими мегапроцессами и всепланетными перестройками климатических условий. Анализу данных факторов посвящено множество работ, которые рассматривают как общемировые тенденции 
изменений (Глобальные изменения..., 2001; Климат ..., 2004), так и региональные тенденции (Пешкова, 1972; Обязов, 2011; Давыдова, 2014).

В результате иссушения и похолодания на территории современного Забайкалья возникли разнообразные биомы, в которых в той или иной степени присутствуют растения ксероморфной природы, устойчивые к длительному дефициту влаги и очень низкой влажности воздуха в значительный период вегетации (весенне-летняя засуха). Однако некоторые представители семейства Роасеае (Gramineae), по-видимому, сформировавшиеся как виды в этом флористическом регионе, приобрели уникальные адаптационные механизмы. Эти особенности позволили им заселить самые неблагоприятные по увлажнению территории и стать доминантами в степных и многих лесостепных сообществах Забайкалья. Но даже среди устойчивых к засухе злаков, например видов родов Роa, Festuca, Stipa, интересным является Tripogon chinensis (Franch.) Hack. - трехбородник китайский.

T. chinensis - единственный представитель рода Tripogon в России, хотя этот тропический род включает около 30 видов, встречающихся в Азии и Африке (один вид отмечен в Америке) (Цвелев, 1976). Злак представляет собой невысокий многолетник, образующий небольшие густые дерновинки. Листовые пластинки щетинковидные, длиной 3-5 см, имеющие ширину до 0,7 мм, по краям волосистые. Колос односторонний с рядами сближенных колосков на оси (Ломоносова, 1990; Пробатова, 2008). Это пастбищное кормовое растение (Цвелев, 1976). Лимитирующими факторами для популяций T. chinensis служат интенсивное животноводство, разрушение местообитаний (разработка карьеров), пожары (Пробатова, 2008).
Вид обитает в строго определенных биотопах, произрастая в петрофитных степях по каменистым вершинам сопок, на поверхностях скал и крупных валунов, часто образуя трехбородниковую низкотравную степь (Цвелев, 1976; Ломоносова, 1990; Пробатова, 2008; Бондаревич, Коцюржинская, 2014, 2015). В Восточном Забайкалье этот засухоустойчивый восточно-азиатский горностепной вид находится на северной границе своего ареала, охватывающего южные районы Забайкальского края, Маньчжурию, Корею, Монголию; отмечен в Еврейской автономной области и Хабаровском крае (Ломоносова, 1990; Пробатова, 2008).

По литературным данным (Пробатова, 2008), численность вида в России составляет от 1 до 5 тыс. экземпляров. Однако в последние годы в результате изучения распространения T. chinensis в Забайкальском крае отмечается, что вид достаточно часто встречается в южных и юго-восточных районах региона. Его численность значительно выше (на два или даже три порядка), к примеру только в одной популяции у с. Курулга (Акшинский район) площадью $3700 \mathrm{~m}^{2}$ находится около

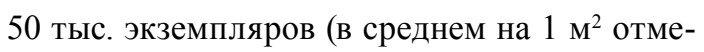
чалось 15 куртин T. chinensis) (Бондаревич, Коцюржинская, 2015).

Для T. chinensis характерно только семенное размножение. Важным свойством многих травянистых растений региона является способность цвести, плодоносить и осуществлять прорастание семян во второй половине лета (Павлова, Якимова, 2004). Это связано с деятельностью над территорией Даурии тихоокеанского муссона, который в этот период времени приносит до $40 \%$ осадков (от общегодового их количества). Семена T. chinensis созревают во второй половине лета, когда температурный режим благоприятен для прорастания и дальнейшего роста проростка, 
поэтому в природе часть семян может прорастать сразу после опадения, а часть - весной. Наблюдения за возобновлением злаков (Дулепова, 1993; Павлова, Якимова, 2004) подтверждают, что в природе семенной подрост появляется в основном за счет урожая семян текущего года и двух предыдущих лет. Незначительное количество зимних и весенних осадков, низкая температура и резкая ее суточная амплитуда, низкая относительная влажность воздуха создают крайне неблагоприятные условия для развития растений весной и в начале лета (Дулепова, 1993; Попова, 2005). Скалы и поверхности каменистых склонов восточной и южной экспозиций в зимний период практически не имеют снегового покрова из-за ветра и ранних оттепелей, сильно нагреваются в весенне-летний период, а толщина почвенного слоя минимальна, либо он вообще отсутствует. Это приводит к быстрому стоку осадков и питательных веществ, промерзанию, резкому перепаду температур в течение суток. Поэтому особый интерес представляют адаптации, обеспечивающие прорастание семян и дальнейший рост $T$. chinensis в экстремальных условиях среды.

Цель работы - изучить биохимические и физиологические механизмы прорастания семян T. chinensis в условиях различной влагообеспеченности и динамику запасных белков семян при прорастании. В задачи входило: 1) изучить динамику прорастания семян $T$. chinensis в условиях разной влагообеспеченности; 2) изучить влияние осмотического стресса на всхожесть семян T. chinensis; 3) рассмотреть особенности использования запасных белков семян при прорастании; 4) определить морфометрические показатели проростков при выращивании в условиях различной влагообеспеченности.

\section{Материалы и методы}

Объектом исследования были зрелые зерновки T. chinensis, собранные в августе 2013 г. в окрестностях с. Курулга (Акшинский район) (площадка 1) и в августе 2014 г. в окрестностях с. Чашино-Ильдикан (Нерчинско-Заводский район) (площадка 2) (рис. 1). Зерновки мелкие,

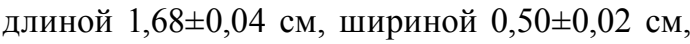
эллипсовидные.

Поверхность семян перед проращиванием стерилизовали 70\%-ным этиловым спиртом в течение минуты, затем 1\%-ным раствором перманганата калия в течение 20 мин и тщательно промывали стерильной дистиллированной водой (Дмитричева и др., 2011).

Для изучения динамики прорастания семян в условиях различной увлажненности субстрата было проведено два эксперимента с семенами, собранными на площадках 1 и 2 соответственно. Проращивание семян проводили на песке в чашках Петри в термостате при температуре $21{ }^{\circ} \mathrm{C}$ в условиях различной влагообеспеченности: влажность песка 30 , 50,70 и $100 \%$ от полной влагоемкости (ГОСТ 12038-84). В каждом варианте было три повторности по 50 семян. Песок перед опытом прокаливали в муфельной печи. В эксперименте с семенами с площадки 1 наряду с оценкой доли проросших семян ежедневно проводили морфометрические исследования - измеряли длину корня и двух листовых пластинок всех проростков $\left(\mathrm{n}_{\min }=3, \mathrm{n}_{\max }=105\right)$.

Для эксперимента по определению динамики запасных белков семена с площадки 1 проращивали в чашках Петри на фильтровальной бумаге, смоченной дистиллированной водой. Растворимые запасные белки семян выделялись последовательно из навески массой \pm 100 мг в трехкратной повторности; для определения запасных белков в проросших семенах брали целиком и семя, и проросток. Фракционирование по Т.Б. Осборну 


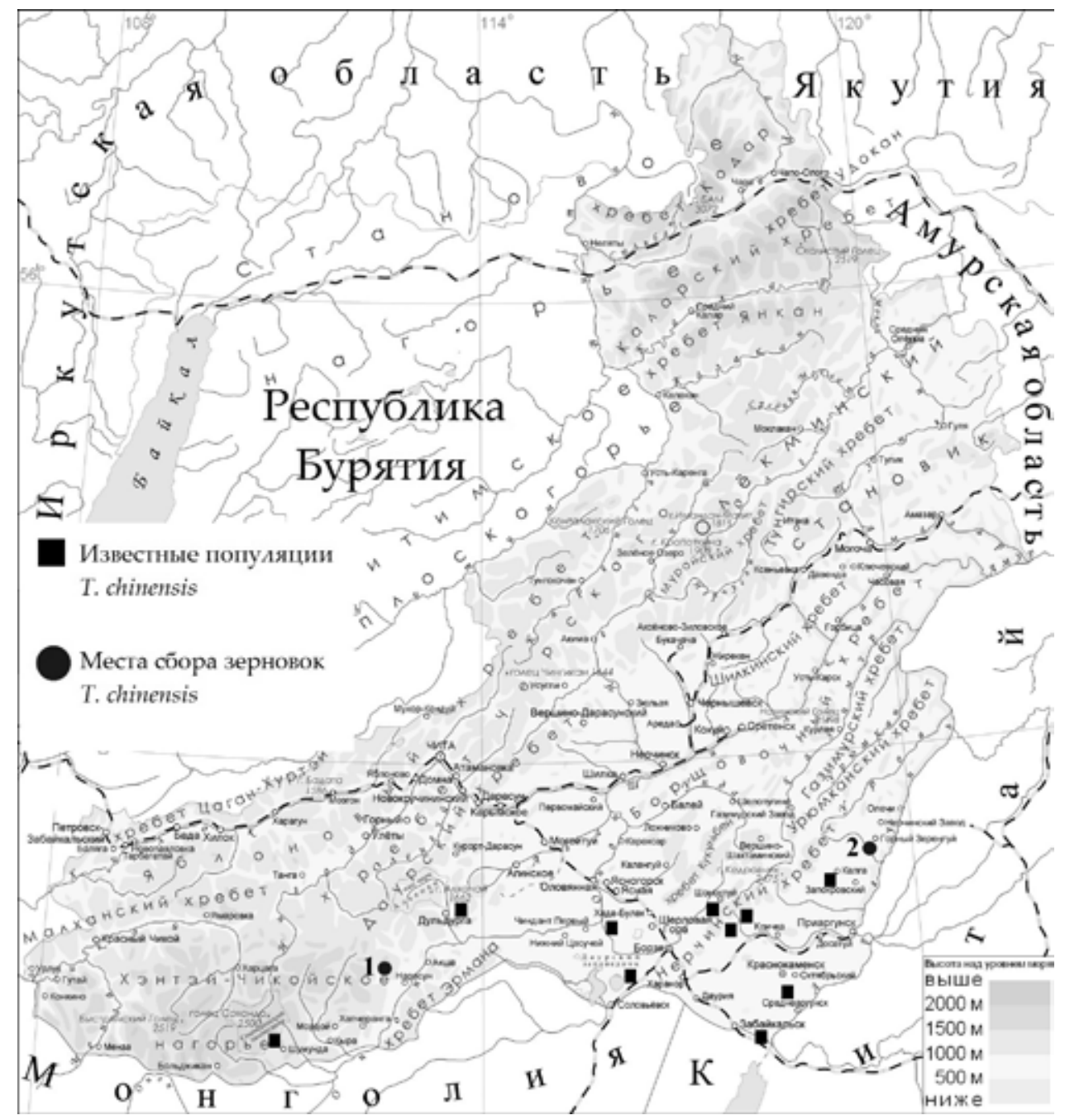

Рис. 1. Распространение T. chinensis в Восточном Забайкалье и места сбора семян (площадка 1 и 2)

Fig. 1. Distribution of T. chinensis in the Eastern Transbaikal region and seed collection sites (sites 1 and 2)

(Хелдт, 2011) проводили по общепринятым методикам (Конарев, 1975; Труфанов, 1994; Биссвангер, 2010; Мошков и др., 2012) с модификациями под дикорастущие злаки (Бондаревич, Осипова, 2010; Бондаревич и др., 2013) и получали экстракты трех протеиновых фракций - альбумины и глобулины (водо- и солерастворимые), проламины (спирторастворимые) и глютелины (кислоторастворимые) объемом 5-7 мл. Для выделения белков семена размалывали в фарфоровых ступках до 70 \% выхода муки, навеску муки обезжири- вали н-бутанолом. Альбумины и глобулины экстрагировали трижды водным раствором $\mathrm{NaCl}, 0,4$ моль/л. Осадок отмывали от электролита и оставшихся альбуминов и глобулинов дистиллированной водой. Проламины получали трехкратной экстракцией 70\%-ным этанолом при комнатной температуре, фракцию глютелиновых белков - трехкратно с 0,1 моль/л уксусной кислотой. Количественно белки определяли фотометрическим методом по методу Lowry при $\lambda=626$ нм (фотометр «Эксперт 003», «Эконикс Эксперт», Россия), с 
реактивом Фолина-Чокалтеу (стандарт - раствор человеческого альбумина 80 мг/мл).

Осмотический стресс разной силы $\left(\mathrm{p}_{\text {осм. }}=5\right.$ (506,6 кПа), $10(1013,25$ кПа), 14 (1419 кПа) и 18 атм. (1824 кПа)) создавали раствором сахарозы в дистиллированной воде, что соответствует 5,93, 11,86, 15,80 и 19,86\%-ной концентрации (Илли и др., 2005). Метод позволяет на ранних этапах онтогенеза определить относительную засухоустойчивость различных видов растений. Эксперимент проводили в трех повторностях, в каждой из которых содержалось по 50 семян, собранных на площадке 1 .

На рис. 2-5 представлены средние значения и их стандартные ошибки. Для расчетов использовали программу MS Excel 2010.

\section{Результаты и обсуждение}

В результате серии экспериментов было изучено прорастание семян $T$. chinensis в условиях различной увлажненности субстрата. Результаты отражены на рис. 2.

Прорастание семян $T$. chinensis в лабораторных условиях при различной влагообеспеченности было отмечено во всех пробах на 4-е сутки. Семена хорошо прорастают при влажности песка $30 \%$, что объясняется ксероморфной природой изучаемого злака, его способностью максимально эффективно использовать воду (средняя всхожесть $55 \%$ ). Более высокая влажность (50 и 70 \%) также способствует прорастанию семян, максимальная всхожесть для семян из обеих популяций отмечается при влажности песка 70 \% (всхожесть 70 и 55 \%) (рис. 2).

Различия всхожести семян из разных популяций можно объяснить несколько различающимися условиями созревания семян, хотя их сбор был осуществлен в одно и то же время (23-25 августа), а также климатическими особенностями районов сбора. По доступ-

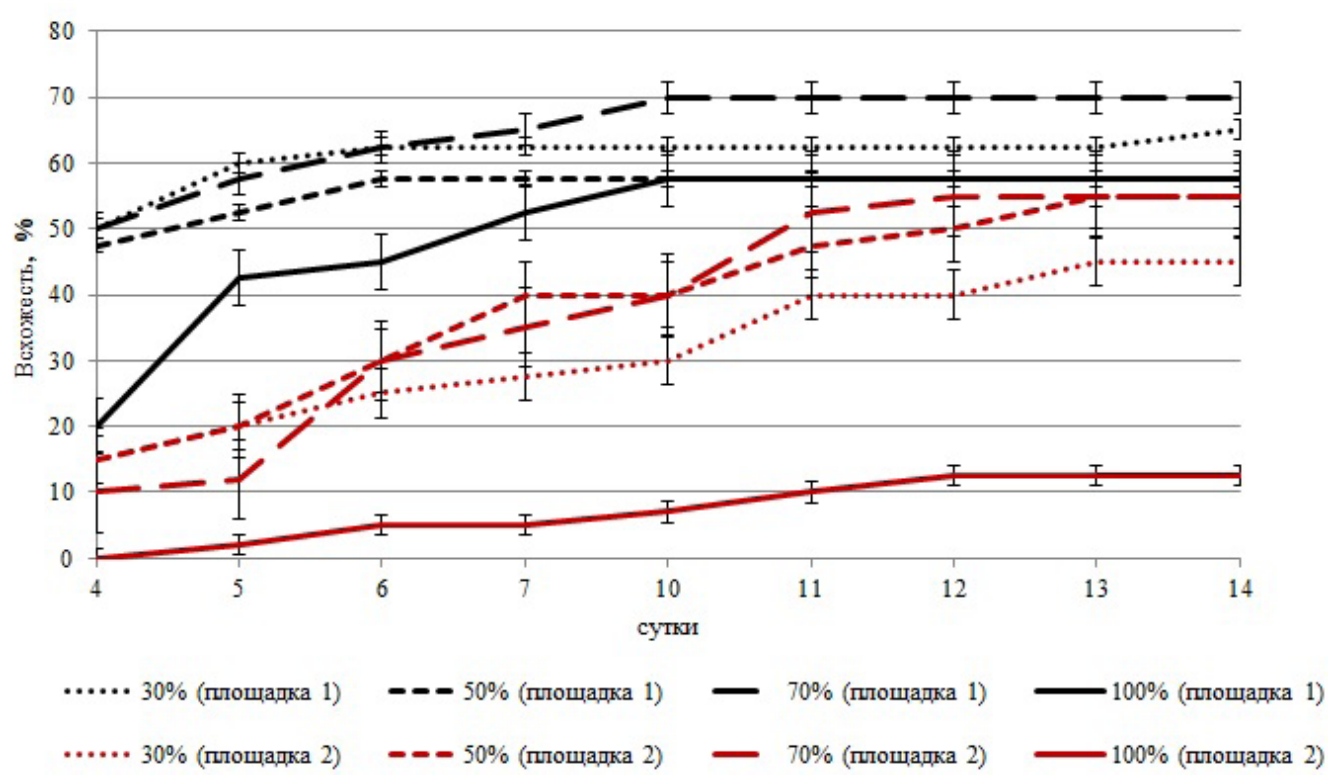

Рис. 2. Динамика прорастания семян T. chinensis (среднее $\pm \mathrm{SE}, \mathrm{n}=3$ ), собранных на площадках 1 и 2, на песке при разной влагообеспеченности (от 30 до 100 \% от полной влагоемкости субстрата)

Fig. 2. Dynamics of germination of T. chinensis seeds (mean $\pm \mathrm{SE}, \mathrm{n}=3$ ), collected at sites 1 and 2, on sand with different moisture content (from 30 to $100 \%$ of the maximum water holding capacity) 
ным метеорологическим данным интернетpecypca Climatebase.ru со станций с. Акша и с. Александровский Завод, расположенных достаточно близко к районам исследований, условия характеризовались следующими особенностями: при широтном движении с востока на запад региона происходит уменьшение количества осадков и относительной влажности воздуха, особенно в вегетационный период, средняя температура повышается, максимальная температура в летний период увеличивается. По этим показателям площадка 1 характеризуется более засушливыми условиями. Также особенностью климата Даурии являются многолетние климатические циклы с периодом около 30 лет, в которых сменяются засушливая и влажная фазы (Мещерская и др., 2009). Период исследования (2013, 2014 гг.) пришелся на начало влажной фазы цикла. Таким образом, семена, собранные в местах с менышей влагообе- спеченностью (площадка 1), имеют большую всхожесть при проращивании в условиях недостатка влаги, оказываясь, таким образом, более адаптированными к водному стрессу.

Избыточное увлажнение (100 \%) негативно сказывается на прорастании семян T. chinensis. Экспериментально установлено, что прорастание наступает позже и процент всхожести оказывается несколько ниже (рис. 2). Избыточное увлажнение способствует развитию сапрофитной микрофлоры, главным образом плесневых грибов, которые приводят к загниванию и гибели зерновок. Гибель семян в подобных условиях также может быть вызвана гипоксией.

В ходе определения всхожести семян были проанализированы морфометрические показатели проростков (длина листовой пластинки, длина корня) T. chinensis в условиях различной увлажненности субстрата (площадка 1) (рис. 3). При влажности субстрата

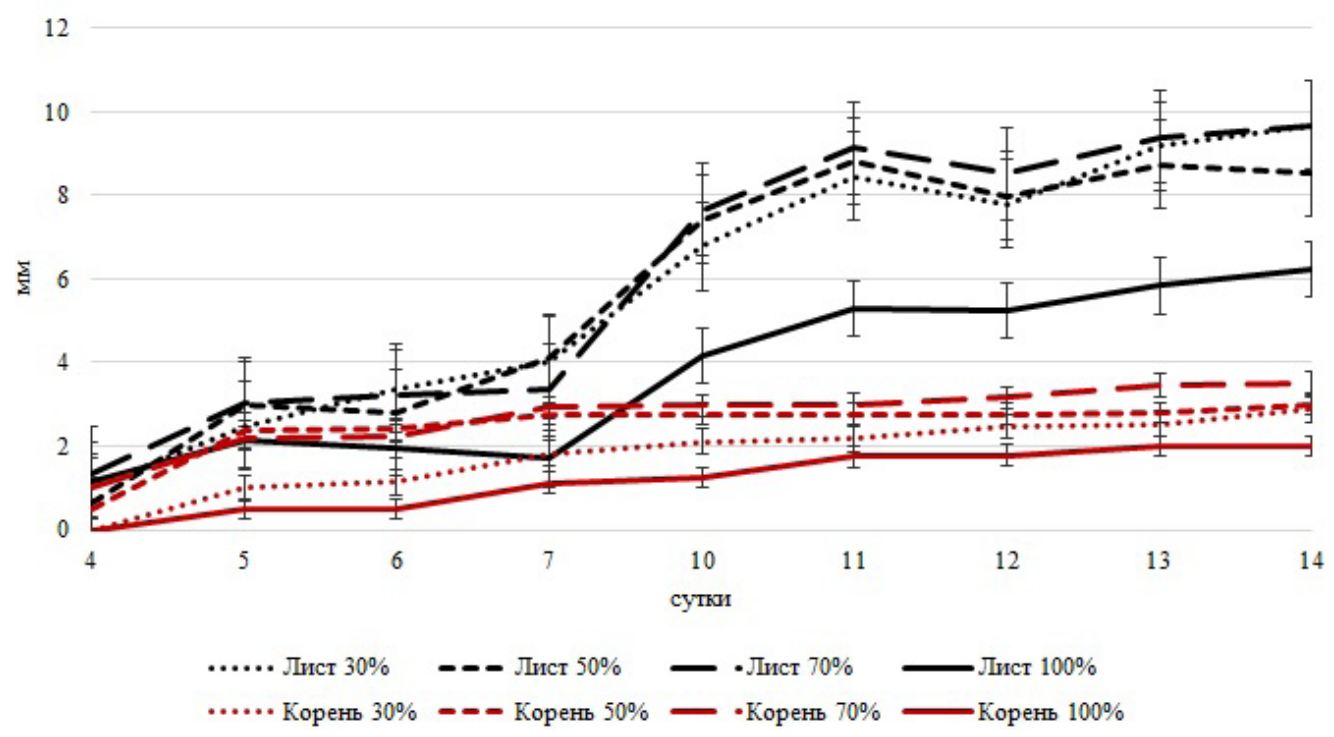

Рис. 3. Динамика средней длины листовой пластинки и корня у проростков T. chinensis (cpeднее $\pm \mathrm{SE}$, $\mathrm{n}_{\min }=3, \mathrm{n}_{\max }=105$ ) при проращивании на песке в условиях разной влагообеспеченности (от 30 до $100 \%$ от полной влагоемкости субстрата). Семена собраны на площадке 1

Fig. 3. Dynamics of average leaf and root lengths of $T$. chinensis seedlings (mean $\pm \mathrm{SE}, \mathrm{n}_{\min }=3, \mathrm{n}_{\max }=105$ ) during germination on sand with different moisture content (from 30 to $100 \%$ of the maximum water holding capacity). The seeds were collected at site 1 
30, 50 и $70 \%$ от полной влагоемкости средние значения линейных параметров листовой пластинки были сходными и концу второй недели проращивания составили в среднем от 8,5 до 9,5 мм. При 100\%-ной влажности песка отмечаются более низкие показатели: средняя длина листовой пластинки в таких условиях на 14-е сутки равнялась 6,2 мм (рис. 3).

При 30,50 и 70\%-ном увлажнении линейные параметры листовой пластинки имели к 14-м суткам очень близкие значения (рис. 3). То есть данный параметр сложно применять для оценки влияния увлажнения субстрата на адаптационные особенности T. chinensis, и злак достаточно эффективно использует условия среды для создания надземной вегетационной массы. Избыточное увлажнение субстрата отрицательно сказалось на ростовых процессах. Темпы роста листовой пластинки во всех условиях увлажнения наиболее интенсивно увеличиваются после 7-х суток прорастания (средняя длина увеличивается почти в 2 раза).

Изменение линейных параметров корня оказалось менее значительным. Средняя длина к концу второй недели прорастания со- ставила от 2 до 3,5 мм. Диапазон влажности субстрата для наилучшего развития корня T. chinensis находится в области от 50 до $70 \%$. Меньшая влажность (30 \%) вызывает замедление роста корня, но постепенно к 14-м суткам корень достигает уровня развития, близкого к наблюдающемуся при 50 \%. При влажности песка $100 \%$ рост корня медленный и к концу эксперимента составил не более 2 мм. Это подтверждает негативное влияние избытка увлажнения на ростовые процессы исследуемого злака. Подобные условия могут вызывать гипоксию, которая приводит к нарушению деления клеток и, как следствие, к угнетению роста.

Для оценки засухоустойчивости T. chinensis на ранних этапах онтогенеза проращивали семена, собранные на площадке 1 , в растворах сахарозы различной концентрации (рис. 4). Осмотическое давление в 5 атм. существенно снижает процент всхожести семян (почти в два раза). При давлении 10 атм. прорастание затягивается еще на сутки, и процент всхожести оказывается в семь раз меньше по сравнению с контролем (влажная фильтровальная бумага). Кроме того, осмоти-

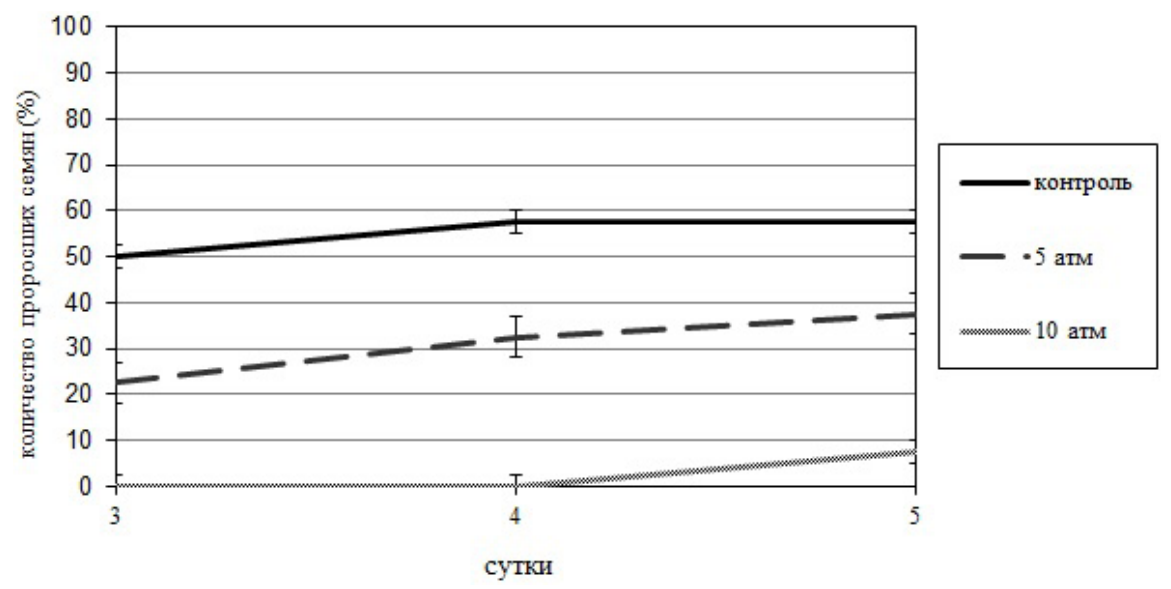

Рис. 4. Динамика прорастания семян T. chinensis, собранных на площадке 1, в условиях осмотического стресса (среднее $\pm \mathrm{SE}, \mathrm{n}=3$ )

Fig. 4. Dynamics of germination of $T$. chinensis seeds collected at site 1 under osmotic stress (mean $\pm \mathrm{SE}, \mathrm{n}=3$ ) 
ческий стресс (5 и 10 атм.) замедляет рост вегетативных органов проростков $T$. chinensis. При более высоком осмотическом давлении (14 и 18 атм.) семена исследуемого злака не проросли. Высокое осмотическое давление раствора, имитируя засуху, вызывает водный стресс у растений, который нарушает поступление воды и запуск ростовых процессов. В целом это приводит к прямым или косвенным нарушениям метаболизма, к дефициту метаболической воды, накоплению различных токсических соединений и недостатку питательных веществ (Сидоров, 1990; Григорюк и др., 2000), что может вызвать остановку прорастания.

Питание проростка до перехода его к автотрофному способу обеспечивают запасы эндосперма. Основными резервными соединениями в семенах злаков являются углеводы (крахмал) и белки. Проросток нуждается в постоянном притоке азотистых веществ, которые выделяются при гидролизе белкового комплекса, они же служат и основным источником аминокислот. Поэтому изучение белкового состава семян имеет важное значение для развития концепции устойчивости растений. Большинство работ в этой области посвящено сельскохозяйственным растениям (Kreis et al., 1985; Верхотуров, 2008; Shewry, Halford, 2002; Осипова, 2011). Злаки, не относящиеся к этой группе, исследовались меньше (Семихов и др., 2006; Бондаревич и др., 2013), хотя для дикорастущих видов растений проблема сохранения жизнеспособности семян, их адаптации к меняющимся условиям среды актуальна. Эти особенности позволяют сохраняться видам в составе фитоценозов в условиях значительной конкуренции и осваивать новые пространства для жизни.

В связи с этим был изучен фракционный состав запасных белков семян $T$. chinensis, так как они вносят существенный вклад в обеспе- чение жизнеспособности семян. Был количественно (в мг белков на г сырой массы) определен фракционный состав запасных белков семян $T$. chinensis и их динамика при набухании и прорастании, а также процентное соотношение белковых фракций (рис. 5).

В ходе исследования выявлены следующие особенности изменения белкового комплекса семян до прорастания и во время этого процесса в оптимальных условиях (рис. 5). Количественно в сухих семенах преобладали альбумины и глобулины, представляющие собой быстро мобилизуемые источники аминокислот в первые часы и сутки прорастания, а также обладающие ферментативной активностью (протеазной, гликозидазной). В первые сутки от начала набухания зерновок эти фракции количественно сокращаются практически вдвое (с 20 до 12 мг/г сырой массы), и в последующие этапы наблюдений их содержание меняется незначительно (рис. 5). Процентное содержание альбуминов и глобулинов меняется от первых к девятым суткам наблюдений не более чем на 5 \%.

Уникальным механизмом адаптации многих злаков, в частности T. chinensis, является накопление проламиновой фракции. Эта особенность приспособления наиболее выражена у внетропических злаков и связана с реализацией ростовых процессов в неблагоприятных условиях прорастания (Семихов и др., 2006). Проламиновая фракция активнее всего расходуется в наблюдаемый период, за который зародыш от гетеротрофного питания переходит к автотрофному и формирует зародышевые листовые пластинки и корень. Так, в сухих зерновках $T$. chinensis содержание проламинов составляло 17 мг/г сырой массы, а через 24 ч снизилось уже до 9,49 мг/г сырой массы, т.е. практически вдвое. В последующие несколько суток их количество изменялось не столь интенсивно, но к 9-м суткам снизи- 

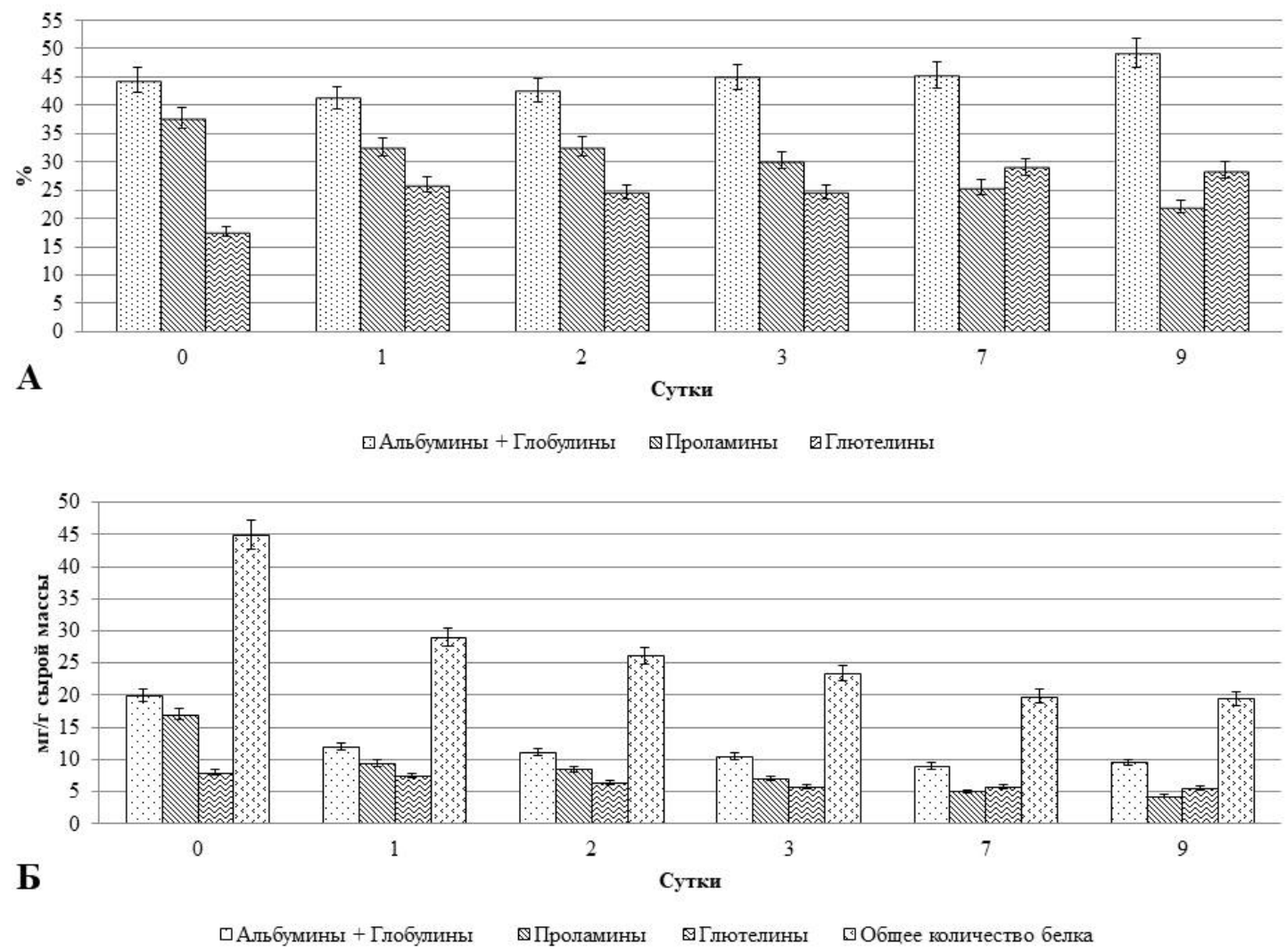

Рис. 5. Динамика фракций запасных белков при прорастании семян T. chinensis, собранных на площадке 1 (среднее $\pm \mathrm{SE}, \mathrm{n}=3$ )

Fig. 5. Dynamics of storage protein fractions during germination of $T$. chinensis seeds collected at site 1 $($ mean $\pm \mathrm{SE}, \mathrm{n}=3$ )

лось до 4,32 мг/г сырой массы, что составило 4-кратное уменьшение (рис. 5). Таким образом, показатель абсолютного и относительного количества проламиновой фракции можно использовать для оценки адаптационного потенциала T. chinensis и определения стратегии выживания в состоянии стресса при прорастании зерновок.

Глютелиновая фракция претерпела не такие значительные изменения. Так, в сухих зерновках T. chinensis содержание глютелинов было 8 мг/г сырой массы, а к девятым суткам от начала набухания и прорастания составило 5,6 мг/г сырой массы. В относительном выражении доля этой фракции возросла более чем на $10 \%$ (1-е сутки - 17,77\%, 9-е - 28,53\%), что, вероятно, имеет две причины. Глютелины образуют гетерогенный комплекс с большим количеством дисульфидных сшивок с проламинами, и в результате работы восстановленного тиоредоксина происходит расщепление этих связей (Хелдт, 2011). Вследствие этого количество экстрагируемого белка возрастает. Второй причиной служит гидролиз белков нерастворимого остатка и переход их в форму отдельных субъединиц, которые и подвергаются экстракции кислотой, повышая количественное содержание фракции.

Известно, что проламины и глютелины богаты пролином, глутамином и глутаматом. Согласно современным представлениям 
о биохимических процессах в растительных клетках (Szabados, Savoure, 2010; Хелдт, 2011) пролин является малотоксичным осмолитом, защищающим растительный организм от обезвоживания или действия осмотического стресса. Также эта аминокислота выступает как один из элементов антиоксидантной защиты, сигнальным веществом и регулятором экспрессии некоторых генов (Кузнецов, Шевякова, 1999). Глутаминовая кислота и глутамин играют ключевую роль в азотном метаболизме.

Роль глютелинов заключается в способствовании выживанию проростков в экстремальных условиях. Известно, что у растений, устойчивых к неблагоприятным условиям обитания, содержание глютелинов значительно выше, чем у восприимчивых (Сергеева, 1971). Имеются данные о значительном содержании глютелинов в семенах таких злаков на территории Забайкалья, как Melica turczaninowiana (относительное содержание глютелинов составляет от 80 до 90 \%), Spodiopogon sibiricus (46\%), Agropyron cristatum (31\%), Festuca litvinovii (46\%) (Бондаревич и др., 2013). Эти виды используют данный механизм адаптации к прорастанию в аридных условиях среды.

\section{Заключение}

Изучение процессов, происходящих на начальных этапах онтогенеза T. chinensis, позволяет внести вклад в исследование адаптации ксерофитных злаков к условиям среды. В петрофитных степях злак оказывается под влиянием комплекса экстремальных факторов среды. Однако T. chinensis формирует в таких местообитаниях наибольшие по численности и плотности популяции.

Одним из адаптационных механизмов является формирование комплекса запасных белков семени. Существенное значение для метаболических процессов, происходящих в прорастающих семенах исследуемого злака, имеют проламины. За счет осмотического действия водорастворимых белков, которые преобладают в белковом комплексе семян, T. chinensis может эффективно использовать почвенную влагу для запуска прорастания, создавая сосущую силу, а активный расход проламинов обеспечивает быстрый переход к ростовым процессам и поступление антиоксидантов и осмолитов.

Выяснено, что семена T. chinensis способны прорастать в широком диапазоне влажности субстрата (от 30 до $100 \%$ от полной влагоемкости). Эта особенность обеспечивает возможность прорастания и перехода к автотрофному питанию в условиях различной влагообеспеченности в природных условиях. Избыточное увлажнение (100 \% от полной влагоемкости субстрата) замедляет прорастание, уменьшая процент всхожести, а также угнетает развитие вегетативных органов проростков T. chinensis. На физиологическую засуху T. chinensis реагирует снижением всхожести семян.

Поскольку исследуемый злак занесен в Красную книгу РФ (категория статуса 2 сокращающийся в численности), Красную книгу Забайкальского края, то изучение особенностей начальных этапов онтогенеза может внести вклад в работы по интродукции T. chinensis с целью сохранения этого вида.

\section{Список литературы}

Биссвангер Х. (2010) Практическая энзимология. М., БИНОМ. Лаборатория знаний, 328 с. [Bisswanger H. (2010) Practical enzymology. Moscow, BINOM. Laboratoriya znaniy, 328 p. (in Russian)] 
Бондаревич Е.А., Осипова С.В. (2010) Высокое содержание глютелинов в семенах реликтового злака Melica turczaninowiana (Poасеаe). Журнал Сибирского федерального университета. Биология, 3(4): 384-390 [Bondarevich E.A., Osipova S.V. (2010) High contents of glutelins in seeds of relic Melica turczaninowiana (Poaceae). Journal of Siberian Federal University. Biology, 3(4): 384390 (in Russian)]

Бондаревич Е.А., Борискин И.А., Якимова Е.П. (2013) Эколого-биологические особенности злаков Восточного Забайкалья. Чита, Экспресс-издательство, 184 с. [Bondarevich Е.А., Boriskin I.A., Yakimova E.P. (2013) Ecological and biological characteristics of cereals of the Eastern Transbaikal region. Chita, Express izdatelstvo, 184 p. (in Russian)]

Бондаревич Е.А., Коцюржинская Н.Н. (2014) Состав фитоценозов на территории Восточного Забайкалья с участием некоторых редких видов: Tripogon chinensis (Franch.) Hack., Zizania latifolia (Griseb.) Stapf и Melica virgata Turcz. ex Trin. (Poaceae). Материаль IV Междунар. научнопрактич. конфер.: Изучение, сохранение и восстановление естественных ландшафтов. Волгоград, Волгоградское научное издательство, с. 20-23 [Bondarevich E.A., Kotsyurzhinskaya N.N. (2014) Composition of plant communities in the Eastern Transbaikal region with rare species: Tripogon chinensis (Franch.) Hack., Zizania latifolia (Griseb.) Stapf and Melica virgata Turcz. ex Trin. (Poaceae). Proceedings of the IV international scientific-practical conference: Study, preservation and restoration of natural landscapes. Volgograd, Volgograd Scientific Press, p. 20-23 (in Russian)]

Бондаревич Е.А., Коцюржинская Н.Н. (2015) Новые местонахождения Tripogon chinensis (Franch.) Hack. (Poaceae) в Восточном Забайкалье. Проблемы ботаники Южной Сибири и Монголии: сборник научных статей по материалам ХIV международной научно-практической конференции. Барнаул, изд-во АлтГУ, с. 12-17 [Bondarevich E.A., Kocjurzhinskaja N.N. (2015) New locations of Tripogon chinensis (Franch.) Hack. (Poaceae) in East Transbaicalia. Problems of botany of South Siberia and Mongolia: proceedings of the XIV international scientific-practical conference. Barnaul, Altai State University Press, p. 12-17 (in Russian)]

Верхотуров В.В. (2008) Физиолого-биохимические процессы в зерновках ячменя и пшеницы при их хранении, прорастании и переработке. Автореф. дисс. ... канд. биол. наук. М., 40 с. [Verkhoturov V.V. (2008) Physiological and biochemical processes in the grains of barley and wheat during storage, germination and processing. Abstract of the thesis for the Candidate of Biol. Sciences degree. Moscow, 40 p. (in Russian)]

Глобальные изменения природной среды (2001) Добрецов Н.Л., Коваленко В.И. (ред.) Новосибирск, изд-во СО РАН, филиал «Гео», 373 с. [Global changes of the natural environment (2001) Dobretsov N.L., Kovalenko V.I. (eds.) Novosibirsk, SB RAS, filial "Geo”, 373 p. (in Russian)]

ГОСТ 12038-84. Семена сельскохозяйственных культур. Методы определения всхожести (2011) М., Стандартинформ, 64 c. [GOST 12038-84. Seeds of agricultural crops. Methods for determination of germination capacity (2011) Moscow, Standartinform, 64 p. (in Russian)]

Григорюк И.А., Петренко Н.И., Шведова О.Е., Ярошенко Е.А. (2000) Водный и азотный обмен зерновых культур в условиях разной водообеспеченности. Физиология и биохимия кульmурных растений, 32(5): 401-409 [Grigoryuk I.A., Petrenko N.I., Shvedova O.E., Yaroshenko E.A. (2000) Water and nitrogen metabolism under cereal crops in conditions of different water availability. Physiology and Biochemistry of Cultivated Plants [Fiziologiya i biohimiya kulturnyh rastenij], 32(5): 401-409 (in Russian)] 
Давыдова Н.Д. (2014) Динамика показателей степных геосистем Юго-Восточного Забайкалья в условиях глобальных изменений климата. Международный журнал прикладных и фундаментальныхх исследований, 4: 120-125 [Davydova N.D. (2014) Dynamics of indicators of steppe geosystems of the South-Eastern Transbaikalia under the conditions of global climate changes. International Journal of Applied and Fundamental Research [Mezhdunarodnyj zhurnal prikladnyh i fundamentalnyh issledovanij], 4: 120-125 (in Russian)]

Дмитричева Д.С., Яппаров А.Х., Дегтярева И.А. (2011) Ризосферные аборигенные микроорганизмы, способствующие росту и развитию растений. Ученые записки Казанской государственной академии ветеринарноймедицины имени Н.Э. Баумана, 207: 186-190 [Dmitricheva D.S., Yapparov A.H., Degtereva I.A. Rizosphere native microorganisms promoting growth and development of plants. Scientific notes of Bauman Kazan State Academy of Veterinary Medicine [Uchenye zapiski Kazanskoj gosudarstvennoj akademii veterinarnoj mediciny imeni N EH Baumana], 207: 186-190 (in Russian)]

Дулепова Б.И. (1993) Степи горной лесостепи Даурии и их динамика. Чита, Изд-во ЧГПИ, 395 c. [Dulepova B.I. (1993) Steppes in the mountain forest-steppe of Dauria and their dynamics. Chita, Chita State Pedagogical Institute, 395 p. (in Russian)]

Илли И.Э., Назарова Г.Д., Половинкина С.В., Парыгин В.В. (2005) Физиология и биохимия растений. Иркутск, 110 с. [Illi I.E., Nazarova G.D., Polovinkina S.V., Parygin V.V. (2005) Physiology and biochemistry of plants. Irkutsk, 110 p. (in Russian)]

Климат в эпохи крупных биосферных перестроек (2004) Семихатов М.А., Чумаков Н.М. (ред.) М., Наука, с. 5-47 [Climate in the epochs of major biospheric transformations (2004) Semikhatov M.A., Chumakov N.M. (eds.) Moscow, Nauka, p. 5-47 (in Russian)]

Конарев В.Г. (1975) Проблема пищевой ценности растительных белков. Растительные белки и их биосинтез. М., Наука, с. 5-20 [Konarev V.G. (1975) The problem of nutritive value of plant proteins. Plants proteins and their biosynthesis. Moscow, Nauka, p. 5-20 (in Russian)]

Кузнецов В.В., Шевякова Н.И. (1999) Пролин при стрессе: биологическая роль, метаболизм, регуляция. Физиология растений, 46(2): 321-336 [Kuznetsov V.V., Shevyakova N.I. Proline under stress: biological role, metabolism, regulation. Plant Physiology [Fiziologiya rastenij], 46(2): 321-336 (in Russian)]

Ломоносова М.Н. (1990) Tripogon Roemer et Schultes - Трехбородник. Флора Сибири. T. 2. Poасеае (Gramineae). Новосибирск, Наука, с. 233 [Lomonosova M.N. (1990) Tripogon Roemer et Schultes. Flora of Siberia. Vol. 2. Poaceae (Gramineae). Novosibirsk, Nauka, p. 233 (in Russian)]

Мещерская А.В., Обязов В.А., Богданова Э.Г., Мирвис В.М., Ильин Б.М., Сницаренко Н.И., Голод М.П., Смирнова А.А., Обязова А.И. (2009) Изменение климата Забайкалья во второй половине XX века по данным наблюдений и ожидаемые его изменения в первой четверти XXI века. Труды Главной геофизической обсерватории им. А.И. Воейкова, 559: 32-57 [Meshcherskaya A.V., Obyazov V.A., Bogdanova E.G., Mirvis V.M., Ilyin B.M., Snitsarenko N.I., Golod M.P., Smirnova A.A, Obyazova A.I. The climate change in the Transbaikal region during the second part of the $20^{\text {th }}$ century based on observation data and expected changes in the first quarter of the $21^{\text {st }}$ century. Proceedings of Voeikov Main Geophysical Observatory [Trudy Glavnoj geofizicheskoj observatorii im A.I. Voejkova], 559: 32-57 (in Russian)] 
Мошков И.Е., Степанченко Н.С., Новикова Г.В. (2012) Количественное определение содержания белка. Молекулярно-генетические и биохимические методы в современной биологии растений. Кузнецов Вл.В. (ред.) М., БИНОМ, Лаборатория знаний, с. 201-212 [Moshkov I.Е., Stepanchenko N.S., Novikova G.V. (2012) Quantification of protein content. Molecular-genetic and biochemical methods in modern plant biology. Kuznetsov Vl.V. (ed.) Moscow, BINOM, Laboratoriya znaniy, p. 201-212 (in Russian)]

Обязов В.А. (2011) Изменения климата в междуречье Аргуни и Онона в контексте глобального потепления. Вестник ЧитГУ, 7: 78-85 [Obyazov V.A. Climate changes between the rivers Argun and Onon in the context of global warming. Bulletin of Chita State University [Vestnik ChitGU], 7: 78-85 (in Russian)]

Осипова C.B. (2011) Ферментативная регуляиия SS/SH редокс статуса запасных белков и качества клейковины пшеницы. Автореф. дисс. ... канд. биол. наук. Иркутск, 40 с. [Osipova S.V. (2011) Enzymatic regulation of SS/SH redox status of storage proteins and quality of wheat gluten. Abstract of the thesis for the Candidate of Biol. Sciences degree. Irkutsk, $40 \mathrm{p}$. (in Russian)]

Павлова Н.Е., Якимова Е.П. (2004) Осенне-зимний покой степных растений Забайкалья. Чита, изд-во ЗабГПУ, 73 с. [Pavlova N.E., Yakimova E.P. (2004) Autumn-winter rest of Transbaikalia steppe plants. Chita, Transbaikal State Pedagogical University, 73 p. (in Russian)]

Пешкова Г.А.(1972) Степная флора Байкальской Сибири. М., Наука, с. 170-185 [Peshkova G.A. (1972) Steppe Flora of Baikalian Siberia. Moscow, Nauka, p. 170-185 (in Russian)]

Попова О.А. (2005) Биоразнообразие и особенности адаптогенеза раннеиветущих растений Байкальской Сибири (Восточное Забайкалье). Чита, изд-во ЗабГПУ, с. 91-104 [Popova O.А. (2005) Biodiversity and features of adaptogenesis of early flowering plants of Baikal Siberia (Eastern Transbaikalye). Chita, Transbaikal State Pedagogical University, p. 91-104 (in Russian)]

Пробатова Н.С. (2008) Трехбородник китайский - Tripogon chinensis (Franch.) Hack. Kpacная книга Российской Федераџии (растения и грибы). Трутнев Ю.П. (ред.) М., Товарищество научных изданий КМК, с. 456-457 [Probatova N.S. (2008) Tripogon chinensis (Franch.) Hack. The Red Book of Russian Federation (plants and mushrooms). Trutnev N.S. (ed.) Moscow, KMK Scientific Press Ltd., p. 456-457 (in Russian)]

Семихов В.Ф., Тимощенко А.С., Арефьева Л.П. (2006) Адаптивный потенциал злаков в интродукиии растений. Пущино, ОНТИ ПНЦ РАН, 49 с. [Semikhov V.F., Timoshchenko A.S., Aref'eva L.P. (2006) Adaptive potential of grain crops in the introduction of plants. Pushchino, Department of Scientific and Technical Information at the Pushchino Research Center of the Russian Academy of Sciences, 49 p. (in Russian)]

Сергеева К.А. (1971) Физиологические и биохимические основы зимостойкости древесных растений. М., Наука, 176 с. [Sergeeva К.А. (1971) Physiological and biochemical basics of winter hardiness of woody plants. Moscow, Nauka, 176 p. (in Russian)]

Сидоров В.А. (1990) Биотехнология растений. Клеточная селекция. Киев, Наукова думка, 280 c. [Sidorov V.A. (1990) Plant biotechnology. Cell selection. Kiev, Naukova dumka, 280 p. (in Russian)]

Труфанов В.А. (1994) Клейковина пшенищы: проблемы качества. Новосибирск, Наука, 166 с. [Trufanov V.A. (1994) Wheat gluten: problems of quality. Novosibirsk, Nauka, 166 p. (in Russian)] 
Хелдт Г.-В. (2011) Биохимия растений. М., БИНОМ. Лаборатория знаний, 471 c. [Heldt H.-W. (2011) Biochemistry of plants. Moscow, BINOM. Laboratoriya znanij, 471 p. (in Russian)]

Цвелев Н.Н. (1976) Злаки СССР. Ленинград, Наука, 788 с. [Tsvelev N.N. (1976) Cereals of the USSR. Leningrad, Nauka, 788 p. (in Russian)]

Kreis M., Forde B.G., Rahman S., Miflin B.J., Shewry P.R. (1985) Molecular evolution of the seed storage proteins of barley, rye and wheat. Journal of Molecular Biology, 183(3): 499-502

Shewry P.R., Halford N.G. (2002) Cereal seed storage proteins: structures, properties and role in grain utilization. Journal of Experimental Botany, 53(370): 947-958

Szabados L., Savoure A. (2010) Proline: a multifunctional amino acid. Trends in Plant Science, 15(2): 89-97 